\title{
Buddhist Women and the Universal Monarch Concept
}

\author{
By: Kustiani ${ }^{1}$
}

(Presented for the $12^{\text {th }}$ Sakyadhita Conference on $12-18^{\text {th }}$ June 2011, Bangkok, Thailand. http://www.sakyadhita.org/home/events.html)

According to the Buddhist texts, there were 16 tribal states (mahäjanapada-s) ${ }^{2}$ in India during the Buddha's time that adopted either republic or monarchical system. Vajjī and Mallā were republicans, while Kosalā, Vañgā, and Magadhā were monarchies. ${ }^{3}$ Neither of these two systems was ranked higher than the other from a Buddhist perspective. ${ }^{4}$ Almost all Indian sources give information that whether the state was a republic or a monarchy, the leaders were all men.

In a monarchical system, the position of a king is the highest political position. In Buddhism, an ideal king is called a universal monarch (cakkavattī). A perusal of Buddhist texts shows that woman is never mentioned of becoming cakkavattī; in fact, the term cakkavatti is always used to refer man. Not to mention of becoming a cakkavattī, there is not even mention of a woman becoming king during the Buddha's time. As far as the historical records are concerned, it is only during the later period that we find the fact that several Buddhist women becoming rulers in Sri Lanka. ${ }^{5}$

\section{Women in Society and Politics as Depicted in Brahmanical Texts}

Indian society prior to the emergence of Buddhism was Brahmanical and patriarchal in their religious and social system. It is said that even in the birthplace of the Buddha, brahmins 
officiated the domestic religious functions of the Sakyan people and settled in the area called Khomadussa. ${ }^{6}$ The influences of Brahmanism were strong and had a deep impact on the mindset of the people. Political life was patriarchal teaching, too; hence, the rulers were predominantly men, especially from the warrior caste (khattiya). ${ }^{7}$

Brahmanic teachings place women lower than men in almost all respects. This is shown in the Laws of Manu (Manusmrti), a fundamental Brahmanical text regarding social organization. According to this text, in religious life, women are not allowed to study religious texts to the extent that men are and there are certain ritualistic mantras that women are prohibited to recite. ${ }^{8}$ Women are regarded as beings who come into the world with their nature to seduce men. ${ }^{9}$ In their social and family lives, women's duties are mostly limited to producing children,

serving their husband, and doing domestic work. ${ }^{10}$ In general, women's roles in Indian society as depicted in the Manusmrti never extend beyond the domestic sphere. It can be said that it was impossible for women in Brahmanical society to have a significant role in political life.

Buddhism does not place women in such a low position as Brahmanism does, though Buddhist texts also do not speak much about the role of women in relation to political life and kingship. Some Buddhist texts mention that a woman will never be able to be an ideal king, cakkavattī. For example, the Anguttara Nikāya clearly says: "It is impossible, monks, it cannot come to pass, that a woman should be an Universal monarch. But, monks, it is quite possible for a man to be an Universal monarch."11

\section{The Buddhist Monarchical Concept and Its Relation to Women}

It is important to keep in mind that the concept of rulers of empires already existed in the Brahmanic society before the emergence of Buddhism. The development of the concept can be 
traced in the Brahmanic texts, such as the Maitryāya Upanishad. ${ }^{12}$ In the Brahmanic society, the concept of a ruler is related to the concept of a god. Rulers of empires are said to be equivalent to the same as the gods Indra and Varuna. ${ }^{13}$

The concept of cakkavatti is found in the earliest texts of the Pāli canon and seems to have been developed later, as the temporal counterpart of the Buddha, who is viewed as a spiritual ruler or leader. ${ }^{14}$ In Buddhism, the concept of cakkavatti is not related to gods. The position of cakkavatti can be gained by any king who is seriously concerned about the welfare of the people, including both their material and spiritual welfare. Socially and politically speaking, a cakkavattī is given a special status in later Buddhist texts. ${ }^{15}$ Not only that, but a cakkavattī is regarded as equal to the Buddha in some aspects, such as working for the happiness of humankind, ${ }^{16}$ and as the teacher of the people. ${ }^{17}$ Well-known cakkavattīs in the Buddhist texts are Dalhanemi ${ }^{18}$ and Mahāsudassana. ${ }^{19}$

Some Buddhist texts praise physical qualities of the cakkavattī. The bodily characteristics of the cakkavatti have been regarded as same with the physical qualities of the Buddha. It is stated that both the Buddha and cakkavattī possess the 32 bodily marks of a great person (mahāpurisa) ${ }^{20}$ These bodily characteristics such as feet with level tread and on the soles of his feet are wheels with a thousand spokes complete with felloe and hub; standing and without bending, he can touch and rub his knees with either hand; and his male organs are enclosed in a sheath. One thing that should be noted in mind is that during the Buddha's time, the concept of the 32 bodily marks was common in the fortune telling and prognostication practices in Indian society. ${ }^{21}$ The fortune telling and prognostication, essentially, was rejected by the Buddha as low art or pseudo science (Tiracchānavijjāa). ${ }^{22}$

Based on the 32 bodily characteristics, it can be found the clue that in order to become a 
cakkavattī, one must be a man. The reason for this is that, there is a requirement in which such a being possesses the vital organ of a man within a sheath (kosohitavatthaguyha). ${ }^{23}$ It then can be assumed that a woman will not be able to be a cakkavattī. This fact was also proved by the commentarial literature of the Angguttara Nikāya. ${ }^{24}$

In the canon, there is a relationship between woman and the concept of cakkavattī; however, it is said that woman is one of the seven treasures of a cakkavatti (woman treasure or itthiratan $\bar{a})$. The six other treasures are: the wheel treasure (cakkaratan̄a $)$, elephant treasure (hatthirataṇa), horse treasure (assarataṇā), gem treasure (maṇirataṇā), household treasure, (gahapatirataṇa), and adviser treasure (parin̄āyakaratan̄ā). ${ }^{25}$ According to descriptions of cakkavattī in the Buddhist texts, a woman must possess certain qualities to be an itthiratana:

...lovely, fair to see, charming, with a lotus-like complexion, not too tall or too short, not too thin or too fat, not too dark or too fair, of more than human, deva-like beauty. And the touch of the skin of the Woman-Treasure was like cotton or silk...Her body smelt of sandal-wood and her lips of lotus... was not unfaithful to the King even in thought, much less in deed. ${ }^{26}$

It is clear that the qualities of woman that are emphasized here are the "feminine" qualities. So far, we do not have any evidence that women were also given the opportunity to make contributions for the development of the country. The greatest worth of a woman is merely producing crown prince for the continuity of the country. Furthermore, it is also still unknown whether a cakkavattī has a wife or many wives as itthirataṇa

Empowering Women in Political Life: Taking the Spirit of the Original Meaning of Mahāpurisa in Relation to Cakkavattī 
Some may ask, why did the Buddha not say that woman can also be a cakkavattî? Does it mean that the Buddha was sexist? We cannot easily make such a judgment. The answer is related to socio-political conditions of Indian society at the given time.

Due to the patriarchal and sexist attitudes of Indian society at the time of the Buddha, it was difficult for women to hold high positions in political life. Women were only involved in the domestic sphere, without access to political knowledge. Even if there were women from royal families who gained access to politics, it would still have been a "social shock" if the Buddha openly admitted that a woman could be a cakkavattī.

When women learn about the Buddhist concept of cakkavattī, some women might never have the courage to participate in political life. They might think that it is useless to engage in politics, because it is not the world they should involve in. When we carefully examine the early and later strata of Buddhist texts, we discover that the reason may not only be a matter of sociopolitical conditions in Indian society of the day, but may also have been different emphasis of the concept of mahäpurisa in the early ${ }^{27}$ and later $^{28}$ Buddhist texts.

The early texts emphasize on mental qualities, while in later texts the concept becomes infused with references to the importance of bodily marks. In defining the concept of the great person, the Buddha had different view comparing to the various notions that prevailed in the Indian society at that time. It is well exemplified in the Vassakāra Sutta of the Anguttara Nikāya where the Buddha defines the great person as the person who is concerned for the welfare and happiness of the humankind, mastered the mind and the way of thought, training the mind well up to certain level such as posses the four jhānas and destroying the defilements of mind by attaining the deliverance of mind (cettovimutti) and the deliverance by wisdom (paññavimutti). ${ }^{29}$

Another explanation of the great person can be found in the Mahāpurisa Sutta of the 
Samyutta Nikāya. ${ }^{30}$ In this sutta the Buddha clearly says that so called great person is the being whose mind is liberated. Hence, it can be assumed that the concept of great person in Buddhism is related to the qualities of spiritual life. One thing that should be noted is that, though the word purisa is masculine in gender, the description of the requirements for a mahapurisa as far as these two discourses are concerned is silent about gender. This status is applicable for all people, women and men. Hence, it can be said that the concept of great person regardless the physical qualities. It is also supported by the Lakunțakabhaddiya Sutta, ${ }^{31}$ which tells the story that even the dwarf ugly person can also attain the liberation of mind and become the person with great spiritual power (mahiddhiko mahānubhāvo). Although the Lakunțakabhaddiya was dwarf ugly person, due to his mental qualities he was praised by the Buddha as beautiful and delight person. ${ }^{32}$ As far as the concept of cakkavatti is also imbued with the concept of great person, it can safely be assumed that the real cakkavatti should fulfill the real mental quality of the cakkavattī.

The purpose here is not to try to provide justification for women to be cakkavattī. Rather, we seek a new perspective that may empower women's role in politics. Women do not need to think about the importance of being qualified to be a cakkavatti. The most important thing is that, women must be able to access the moral teachings that underlie the cakkavatti concept. Here, we want to focus on the inner spiritual qualities of a cakkavatti rather than the physical characteristics. Emphasis is on the essential quality or service that a "cakkavattī had to conduct in accordance with the Dhamma, providing the right watch, ward and protection to the people (dhammika-rakkhāvarā gutti ). ${ }^{, 33}$ It is said that when the king is righteous and keeps the precepts, a wheel-turning monarch (cakkavattī) will appear in the kingdom. ${ }^{34}$

By trying to fulfill the mental requirements for becoming a mahapurisa and considering 
the real meaning of cakkavattī as the king who fulfills the ariyan duties (ariyam cakkavattīvatta), women can become leaders. ${ }^{35}$ Women can become leaders of their community, country, or even the world. Though it may be difficult for women to gain the title cakkavattī, they can become leaders as great as cakkavattī.

Many Buddhist women can be taken as the role models of successful leaders. A woman king named Sima in the Kalinga kingdom of ancient Indonesia was a just ruler in the $7^{\text {th }}$ century CE. ${ }^{36}$ In contemporary times, we can take the examples of Sirimavo Bandaranaike of Sri Lanka, who in 1960 became the first woman prime minister in the world, and Aung San Suu Kyi, the democratic leader in Burma, who won the Noble Peace Prize in 1991. They are examples of the changes for humankind that great women can bring through their role in politics.

\footnotetext{
${ }^{1} \mathrm{PhD}$ student of the Postgraduate Institute of Pali and Buddhist Studies, University of Kelaniya, Sri Lanka.

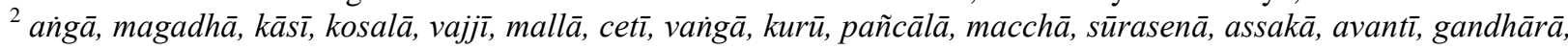
kambojā. A.N. I, 212.

${ }^{3}$ Abeynayake, Oliver. The Fundamental of Buddhist Polity. Singapore: Ti-Sarana Buddhist Association, 1995, pg. 30 .

${ }^{4}$ Op.cit.pg 31

${ }^{5}$ For example, Lilavati, Sivali and Anula. They governed the country only in short period of time. Anula, for example, was the woman King in Sri Lanka who ruled the country for about four months. Anula was told as bad queen, "lewd woman" because she killed many men. See: Malalasekera, G.P. Dictionary of Pāli proper Names. London: PTS, 1974, pg.93.

${ }^{6}$ Davids, T.W. Rhys. The Story of the Nations: Buddhist India. London: T Fisher Unwin, 1903, pg 21. Cf. Khomadussa Sutta of the S.N. I, 183.

7 "as it was the khattiya who had control of the social and political patterns which grew out of the monarchical arrangement...." see: M.M.J. Marasinghe. Gods in Buddhism. Nugegoda. Sri Lanka: Sarasavi Publishers, 2009, pg. $40 \mathrm{f}$

${ }^{8}$ In doing a sacrifice called agnihotra (fire sacrifice), it is only done by males of the three Aryan varnas (except sudra). The sacrifice may be performed by women and Sudras also, but without the recitation of mantras. Buhler, G. The Laws of Manu. Oxford: Clarendon Press, 1886, pg. 32

9 "It is the nature of women to seduce men in this (world); for that reason the wise are never unguarded in (the company of) females". Op.cit, pg. 69.

${ }^{10}$ See the Law of Manu regarding Family life. Op.cit, pg. $75 \mathrm{ff}$
} 
11 "Atțhānametam, bhikkhave, anavakāso yam itthī rājā assa cakkavattĩ. Netaṃ țānam vijjati. Thānañca kho etaṃ, bhikkhave, vijjati yam puriso rājā assa cakkavattī. Thaānametam vijjatï". A.N. I, 28.

12 "There are other great ones, mighty wielders of bows, rulers of empires, Sudyumna, Bhûridyumna, Indradyumna, Kuvalayâsva, Yauvanâsva, Vadhryasva, Asvapati..." Müller, F. Max. The Sacred Books of The East. Vol. XV. Oxford: Clarendon Press, 1884, pg. 289.

${ }^{13}$ Sanath Kumara Nanayakkara. "Cakravartin"in Encyclopaedia of Buddhism, Vol. III. Sri Lanka: The Government of Sri Lanka, 1977, pg. 592 ff

${ }^{14}$ Op.cit, pg. 594

15 "Though this relation between the Mahāpurisa concept and the Buddha and cakkavattī concepts is mentioned in the canon itself, it could be that this belongs to the later stratum...". Wimalaratana Bellanwila. "Mahapurisa" in Encyclopaedia of Buddhism, Vol.VI. Sri Lanka: The government of Sri Lanka, 2002, pg. 468

But, early texts said that it is better to be a Sotapanna than a cakkavattī because a cakkavattī will just be born in heavenly realm only. "kiñcāpi, bhikkhave, rājā cakkavattī catunnam dīpānam issariyādhipaccam rajjam kāretvā kāyassa bhedā param maraṇā sugatim saggam lokam upapajjati devānam tāvatimsānam sahabyataṃ. S.N.V, 341.

${ }^{16}$ puggalā loke uppajjamānā uppajjanti bahujanahitāya bahujanasukhāya, bahuno janassa atthāya hitāya sukhāya devamanussānaṃ. A.N. I, 76

${ }^{17}$ puggalā loke uppajjamānā uppajjanti acchariyamanussā. Op.cit.

${ }^{18}$ Bhūtapubbam, bhikkhave, rājā daḷhanemi nāma ahosi cakkavattī. D.N. III, 58. Cakavattīsīhanāda Sutta.

${ }^{19}$ D.N. II, 47. Mahāparinibbāna Sutta.

20 "... mahāpuriso āyatapanhi hoti...pe ... dīghanguli hoti... mudutalunahatthapādo hoti... jālahatthapādo hoti... ussankkhapādo hoti... enijangho hoti... thitakova anonamanto ubhohi pānitalehi jaṇnukāni parimasati parimajjati... kosohitavatthaguyho hoti... idampi, bhikkhave, mahāpurisassa mahäpurisalakkhanam bhavati”. Lakkhaṇa Sutta. D.N.I. 141.ff. Maurice walse. The Long Discourses of the Buddha. Boston: Wisdom Publications, 1995, pg. $441 \mathrm{ff}$

${ }^{21}$ Wimalaratana, Belanvila. Concept of Great Man. Singapore: Buddhist Research Society, pg. 20

22 “añgam nimittam uppātam supinam lakkhanam mūsikacchinnam aggihomam dabbihomam thusahomam kanahomam tandulahomam sappihomam telahomam mukhahomam lohitahomam añgavijja vatthuvijja khattavijjā sivavijjā bhütavijjā bhürivijja ahivijjā visavijjā vicchikavijjā mūsikavijjā sakunavijjā vāyasavijjā pakkajjhānam saraparittānam migacakkam iti vā iti evarūpāya tiracchānavijjā micchājūvā̄ D.N. I, 8. Brahmajāla Sutta

${ }^{23}$ Rājā assa cakkavattītiādīsupi yasmā itthiyā kosohitavatthaguyhatādīnam abhāvena lakkhaṇāni na paripūranti, itthiratanābhāvena sattaratanasamañgitā na sampajjati, sabbamanussehi ca adhiko attabhāvo na hoti. Tasmā “ațthānametam, bhikkhave, anavakāso yạ̣ itthī rājā assa cakkavattī’ti vuttaṃ. A.N. A. II. 15

${ }^{24}$ Rājā assa cakkavattīitiādīsupi yasmā itthiyā kosohitavatthaguyhatādīnam abhāvena lakkhanāni na paripūranti, itthiratanābhāvena sattaratanasamangitā na sampajjati, sabbamanussehi ca adhiko attabhāvo na hoti. Tasmā “aț̣̂ānametam, bhikkhave, anavakāso yam itthī rājā assa cakkavattī’'ti vuttam. A.N.A. I, 14

${ }^{25}$ Tassimāni satta ratanāni bhavanti. Seyyathidam - cakkaratanam, hatthiratanam, assaratanam, maniratanam, itthiratanam, gahapatiratanam, parināyakaratanameva sattamam. D.N. I. 88. (Ambațha Sutta). D.N. II, 13 (Mahāpadāna Sutta)

${ }^{26}$ Mahā Sudassana Sutta. D.N. II, 175. Cf. Maurice walse. The Long Discourses of the Buddha. Boston: Wisdom Publications, 1995, pg. 208.

${ }^{27}$ A.N. III, 35/ Samyutta Nikāya/ Parayana Vagga of the Sutta nipāta. 
${ }^{28}$ Mahāpadāna Sutta, Mahālakkhana Sutta

${ }^{29}$ Catūhi kho ahaṃ, brāhmaṇa, dhammehi samannāgatam mahāpañ̃am mahāpurisam pañ̃āapemi. Katamehi catūhi? Idha, brāhmaṇa, bahujanahitāya pațipanno hoti bahujanasukhāya; bahussa janatā ariye ñāye patiț̣̂āpitā, yadidam kalyāṇadhammatā kusaladhammatā. So yam vitakkaṃ ākan்khati vitakketum tam vitakkam vitakketi, yam

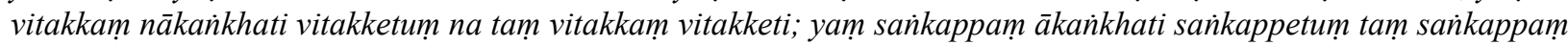
san்kappeti, yam san்kappam nākan்khati san்kappetum na tam san்kappam sañkappeti. Iti cetovasippatto hoti vitakkapathe. Catunnam jhānānam ābhicetasikānam diț̣adhammasukhavihārānam nikāmalābhī hoti akicchalābhī

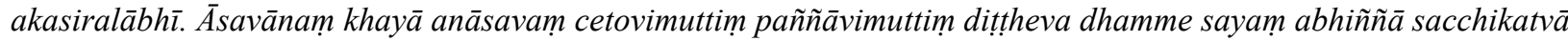
upasampajja viharati. Neva kho tyāham, brāhmaṇa, anumodāmi na pana pațikkosāmi. Imehi kho aham, brāhmaṇa, catūhi dhammehi samannāgatam mahāpaññam mahāpurisaṃ pañ̃̄āpeti A.N. II, 35

30 "With a liberated mind, I say, Sariputta, one is a great man. Without a liberated mind, I say, one is not a great man (Vimuttacittattā khvāham, sāriputta, 'mahāpuriso'ti vadāmi. Avimuttacittattā 'no mahāpuriso'ti vadāmi')”. S.N. V, 157

${ }^{31}$ S.N. II, 278

${ }^{32}$ Mañjussarānaṃ yadidạ̣ lakuṇụaka bhaddiyo. A.N. I, 23

33 A.N.I, 109

34 "If you perform the duties of an Ariyan wheel-turning monarch, on the fast- day of the fifteenth...the sacred Wheel-Treasure will appear to you, thousand- spoked, complete with felloe, hub and all appurtenances." Cakkavattī Sīhanāda Sutta. III.61 Transaltion: Walse, Mauriche. The Long Discourses of the Buddha.Boston: Wisdom Publication, 1995, pg. 396.

35 "Depending on the Dhamma, honouring it, revering it, cherishing it, doing homage to it and venerating it, having the Dhamma as your badge and banner, acknowledging the Dhamma as your master, you should establish guard, ward and protection according to Dhamma for your own household, your troops, your nobles and vassals, for Brahmins and householders, town and country folk, ascetics and Brahmins, for beasts and birds". Op.cit.

${ }^{36}$ Majumdar, R.C., Ancient Indian Colonies in Far East, Vol. II. Suvarnadvipa. Dacca: Asoke Kumar Rajumdar, 1937. Pg. 113 